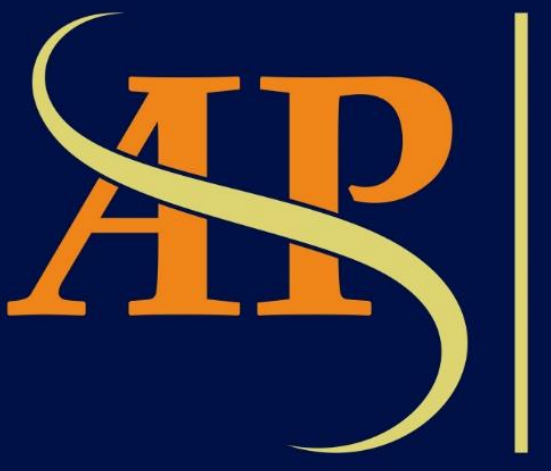

JURNAL

ASIA

PACIFIC

STUDIES

Journal of International Relations Study Program Faculty of Social and Political Sciences

Universitas Kristen Indonesia

Volume I | Number 1 | January- June 2017 


\title{
THE VICTORY OF SOLIDARISM IN GLOBAL GOVERNANCE CASE STUDY OF FOREST FIRES AND TRANSBOUNDARY HAZE IN INDONESIA
}

\author{
Yanyan Mochammad Yani \\ International Relations Department, Universitas Padjajaran, Jl Raya Bandung Sumedang 21, Jatinangor, \\ Kabupaten Sumedang, Jawa Barat, 45363 \\ E-mail: yan2m@hotmail.co.id
}

\begin{abstract}
Solidarism and pluralism are key concepts of English School theory. Solidarism have many differences with pluralism which sometimes contradicting each other. Solidarism has inspired many international projects in dealing with many international problems including Roundtable Sustainable Palm Oil (RSPO) in the context of forest fires and transboundary haze in Indonesia. Solidarists perceived that RSPO is an effective solution in combatting forest fires and transboundary haze in Indonesia. This article would like to question the hegemony of solidarism in global governance with the case study of RSPO in mitigating forest fires and transboundary haze in Indonesia.

This articles has three findings. Firstly, RSPO as solidarism projects has its advantages and weaknesses that need for constant reform and revision. Secondly, pluralism is not neglecting the global governance as there is ASEAN Agreement on Transboundary Haze Pollution that combined global governance with sustainable development and legitimacy. Thirdly, the rivalry of solidarism and pluralism can be neatly put under the heading of global governance.
\end{abstract}

Keywords: pluralism, solidarism, English School, forest fires, transboundary haze

\begin{abstract}
Abstrak
Solidarisme dan pluralisme adalah konsep penting dalam teori English School. Solidarisme memiliki banyak perbedaan yang bertolak belakang dengan pluralisme. Solidarisme telah mendorong pelaksanaan berbagai inisiatif sebagai solusi dari berbagai masalah internasional termasuk Roundtable Sustainable Palm Oil (RSPO) dalam konteks mitigasi kebakaran hutan dan pencemaran udara di Indonesia. Solidarisme mengajukan hegemoni global governance yang ditunjukkan dalam dukungan penuh terhadap RSPO di dalam mencegah terjadinya kebakaran hutan dan pencemaran udara di Indonesia. Artikel ini hendak mengkritisi hegemoni solidarisme dalam global governance melalui studi kasus RSPO dalam mitigasi kebakaran hutan dan pencemaran udara di Indonesia.

Penelitian ini memiliki tiga kesimpulan. Pertama, RSPO sebagai salah satu inisiatif solidarisme memiliki kelebihan dan kelemahan yang memerlukan reformasi dan revisi konstan. Kedua, pluralisme memiliki analisis yang mendalam terkait global governance dengan studi ratifikasi ASEAN Agreement on Transboundary Haze Pollution oleh Indonesia pada tahun 2014. Ketiga, rivalitas antara pluralisme dan solidarisme dapat dipersatukan dalam sebuah konsep global governance.
\end{abstract}

Kata kunci: pluralisme, solidarisme, English School, kebakaran hutan, pencemaran udara. 


\section{Background}

English School has gained its popularity among the European scholars as Barry Buzan has launched the annual conference for gathering English School scholars since 2002. English School theory has attracted attention from International Relation community because it is considered effective in explaining many complex and dilemmatic issues such as humanitarian intervention, international law or regional integration. In environmental issues, there are many noted English School studies such as Kopra (2016) and Falkner (2012).

English School has two core concepts namely pluralism and solidarism. Pluralism equals to the theory of realism that emphasized the self-help structure, state-centric mode and high politics issues meanwhile solidarism is similar to the liberalism that excels the idea of non-traditional issues, regional integration and international law (Buzan 2004). In this article, pluralism advised the state to have more active role in preventing and mitigating transboundary haze. Solidarism believed that the transboundary mitigation can go beyond the state-centric framework. Corporation and civil society can be considered as new actor that powerful in influencing state and create new sphere of decision-making process. Roundtable Sustainable Palm Oil and Forest Stewardship Council are examples on the role of alliance of corporation and civil society in the global governance in the forms certification company (Humphreys 2006). They consists of new forces in campaigning environmental norms and values. They are perceived to be effective due to its influence in people's daily life and its economic and financial power especially their ability to lobby decision-makers.

This article would like to compare the pluralism and solidarism in the case study of transboundary haze and forest fires in Indonesia. Pluralism and solidarism are key concepts of English School and has conflictual and contradicting characteristics. The presence of Roundtable Sustainable Palm Oil (RSPO) and Forest Stewardship Council (FSC) is seen part of solidarism projects and it has been integral part of sustainable agriculture in Southeast Asia. Environmental activists supported the idea of green certification because it is considered more effective and efficient in combatting transboundary haze and forest fires in Indonesia.

\section{Forest Fires and Transboundary Haze Pollution}

Transboundary haze is a destructive environmental disaster that harm people's health and regional economy. Acute respiratory diseases are common to the individuals that breathe air pollution. Transboundary haze is closely related to deforestation and illegal logging. Varkkey (2012) and Bram (2012) wrote that companies that cleared the forest for agricultural farming and plantation used fires as it is the most profitable way compare to zero burning technique. It is also evident that illegal logger used fires to obtain national protected forests for plantations(Varkkey 2009). After the forests are fired, the illegal logger will take it to be their property.

Malaysia and Singapore have been the largest victim of forest fires and transboundary haze. Forest fires and transboundary haze in 1997 is the worst disaster as more than 200.000 peoples in Malaysia, Singapore and Indonesia sought treatment for exposure to high levels of pollution (Dauvergne 1998). They have stopped their daily activities in schools, hospitals, airports, seaports and government offices and harmed people's lives. F1 racing competition must be postponed in 2009 due to the acute haze in the circuit and there have been many protests and demonstration from Malaysian citizen toward inability of Indonesian government combatting forest fires and transboundary haze (Varkkey 2011). 
Figure 1. The Haze as seen from Esplanade Bridge Singapore in 2015

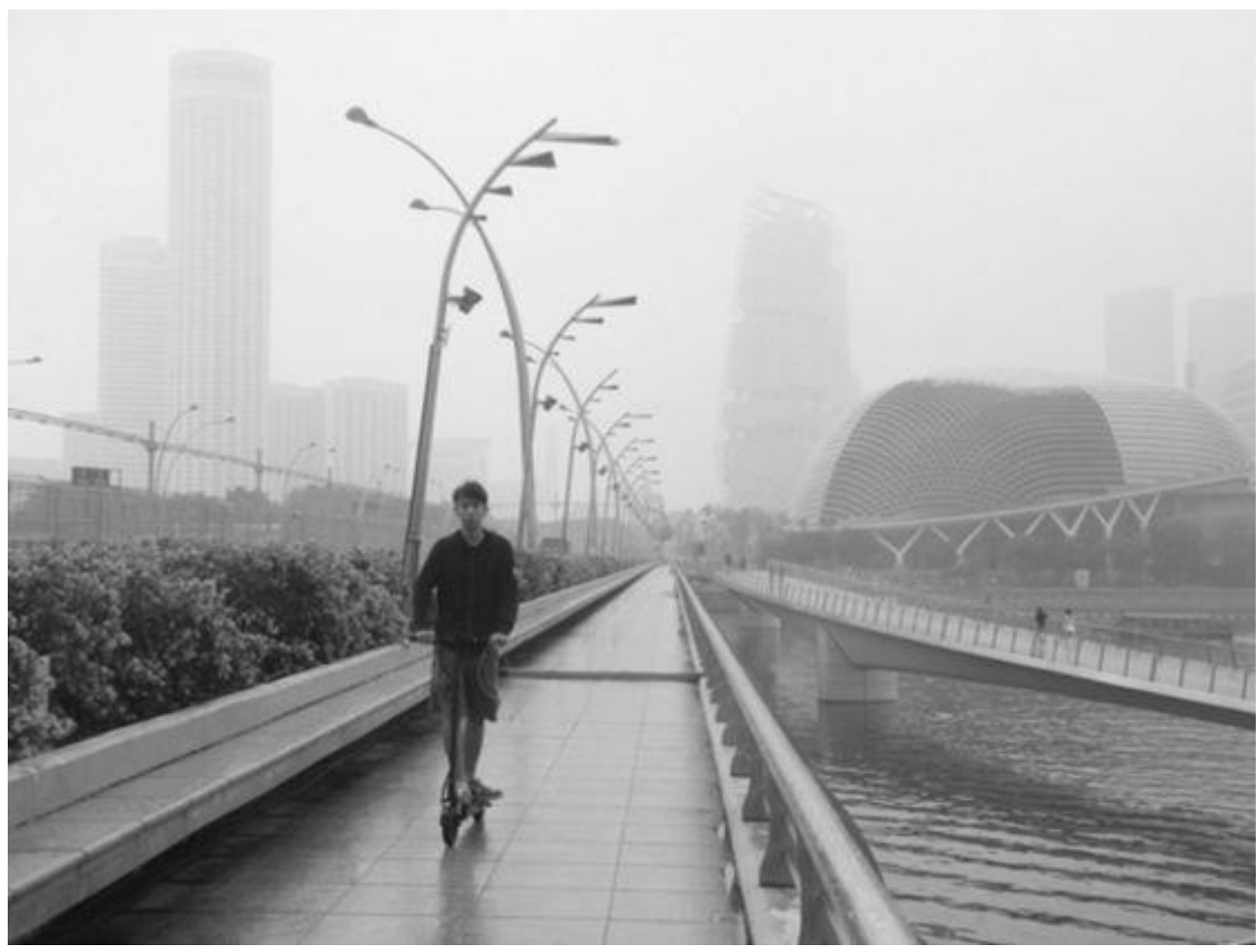

Source: Tan 2015

Forest fires have also kill endangered species such as Orang Utan. Forest as the emission absorber is very important in mitigating the impact of climate change and forest fires have eliminated most of forest areas in Indonesia (Dauvergne 1994). It provokes world wide attention as Greenpeace escalated their campaign to ban forestry products that comes from Indonesian forest (Greenpeace 2007). Indonesia is also blamed for its emissions that comes from forest fires. Due to the forest fires, Indonesia is the third largest carbon emitter in the world after United States and China.

\section{English School}

The scholar of English School are interested in looking the complexity of international problems. English School has some parallels to critical theory and postmodernism where it denied the permanent supremacy of certain values and norms. Hedley Bull and Martin Wight, the founder of English School, argued that the International Relations students need to expand the theoretical framework beyond the dichotomy of Realism and Liberalism. Martin Wight (1992) introduced the trichotomy of realism, revolutionism and rationalism meanwhile Hedley Bull (1977) introduced the concept of international society that consisted of international law, balance of power, great power, war and diplomacy.

The basic idea of English Schoolcomes from the dichotomy of solidarism and pluralism. Hedley Bull (1966) firstly introduced the dichotomy in discussing the possibility and factors for states complying international law. The dichotomy of solidarism and pluralism is not aimed to bring simplicity and parsimony in International Relations. Instead it offers a 
way for criticizing the mainstream and dominant thinking and framework by treating pluralism and solidarism as a continuum debate. The normative dimension of English School is to bring the hidden, invisible and inconvenient truth to the International Relations community and was possibly transformed into a concrete policy action.

The basic of idea of English School is equality. There is no such hegemon thinking or concepts that able to dominate the International Relations community because the International Relations students have different interests and purposes in their intellectual scholarship. The presence of state, for example, is not the hegemon as there are increasingly powerful civil society, media and corporation. The notion of equality means that there is a constant two-way dialogue between the researcher and the research. The ability to grasp the diversity and complexity is the result of the emphasis on the constant dialogue between solidarism and pluralism.

Solidarism is rooted on the cosmopolitan ideals. Charles Beitz is one of the supporter of solidarism and he stated that state of nature is not a permanent situation of international affairs (Beitz 1979). Anarchy is the departure of the logical argument saying that normative ideals such as human rights, justice, and ecosystem balance are utopian. In the situation of anarchy where there is absent of superior authority, states are focusing in achieving their security and welfare to make sure their survival.

Beitz (1979)argued that norms and values are important for states because of four reasons. Firstly, International Relations are not only about states. Globalization has brought new actors that are powerful in terms economic, politics and social cultural. Microsoft has more income than the combined income of African Union and Greenpeace is able to defeat the government plan to open the oil mining in the protected nature of Arctic Sea for endangered species (Cohn 2012). The presence of these new actors brings new ideas and norms to daily international politics. Secondly, international society consists of weak power, major power and great power. This power distribution brings implication to the agenda and norms setting. The great power is able to steer the major power and weak power to comply certain norms and values that possibly not relevant to their interests.

Thirdly, states are interdependent in the sense that states need the assistance of other states to run their daily activities (Beitz 1979). If there is a chaos and internal conflict in a country, it can have a domino effect, spreading and expanding to other states as well. The increasing speed of transportation technology and information access enabled the individuals to bring weapons to other countries. This situation urged governments to create a common strategy and policy. Lastly, there are reliable expectations of reciprocal compliance by the actors with rules of cooperation in the absence of a superior power capable of enforcing these rules.

\section{The limits of pluralism}

Hedley Bull is one of the noted pluralists by arguing that states have the resources and the legitimacy of solving many global problems. Despite of increasing power of civil society and multinational corporation, states have the only political legitimacy in the international affairs. This political legitimacy would outweigh the normative ideals of solidarism. Bull said:

\footnotetext{
"There is, indeed, no lack of self-appointed spokesmen of the common good of 'the spaceship earth' or 'this endangered planet'. But the views of these private individuals, whatever merit they may have, are not the outcome of any political process of the assertion and reconciliation of interests. In the sense that they are not authenticated by such a political process, the views of these individuals provide even less of an authoritative guide to the common good of mankind than do the views of the spokesmen of sovereign states, even unrepresentative or tyrannical
} 
ones, which at least have claims to speak for some part of mankind larger than themselves. Nor do the spokesmen of non-governmental groups (such as bodies of experts on arms control, economic development or environmental matters) possess authority of this kind; they may speak with authority on their particular subject, but to define the interests of mankind is to lay claim to a kind of authority that can only be conferred by a political process (Bull 1977, 83)."

Bull's quote is understandable in the context of 1970s when the main theme of International Relations was decolonization and modernization. Modernization emphasized the primacy of state and bringing the aggressive non-state actors into international organizations will disrupt the noble goals of national welfare and global peace. This article argued that this quote is obsolete as there are many non-state actors that are able to work with the states to achieve normative goals such as human rights. Bull's quote would be seen as the extreme position of contemporary pluralism.

For example, there was a movement called Tony 2012, a campaign by the Invisible Children to arrest Joseph Kony, a rebel group leader. Kony is responsible of genocide and systematic rape and child soldier(Gregory 2012). However, there are no serious actions to arrest him. Invisible Children was able to gain support from United States (US) government to deploy US additional military support to arrest him. Tony 2012 is one of few example that would make the extreme position of pluralism obsolete.

Pluralism and solidarism debate is a core foundation of English School and there is no scholars criticize the relevancy of this dichotomy. This dichotomy aimed to discover the complexity and the dynamics of international issues. It wanted to criticize of the hegemony of pluralism or solidarism and bring the hidden and invisible voice of pluralism or solidarism. However, this dichotomy is prone to be a tool to bring the solidarism and pluralism into a conflict. This research argued that solidarism and pluralism can be neatly put under a single primary institution of global governance by using the case study of forest fires and transboundary haze in Indonesia.

This article will take transboundary haze in Indonesia as the case study. Palm oil corporation are main contributor to government income and local economy. They are expanding significantly to fulfill the global need of palm oil for shampoo, soap or chocolate. Fires are common to be used to clear the land and replanting the palm. However, Indonesia was facing environmental crisis due to the land fires which resulted to transboundary haze to neighbors such as Malaysia and Indonesia. Company-made fires was one of the main factors of forests fires and transboundary haze. Government has banned the fires but it was perpetual disaster and state-centric framework is considered as a failure.

\section{Global Governance}

Global governance is a new primary institution of international society. Barry Buzan (2004) and Hedley Bull (1977) didn't include global governance in their list of primary institution. Paterson (2005) crafted the concept of global environmental governance inspired by Bull's writing however he failed to explain the relevancy of pluralism and solidarism in his way of constructing global environmental governance. To make English School more relevant in the contemporary International Relations issues, English School scholars need to define global governance. Most of the definition of global governance comes from liberalism and cosmopolitan thought. This is a chance for English School scholars to offer their different understanding with liberalism and cosmopolitanism.

Barry Buzan has mentioned the importance of secondary institutions. Primary institutions need to be followed by secondary institutions to elaborate and deepen the meaning of primary institutions. From the case of forest fires and transboundary haze pollution in 
Indonesia, it can be seen that sustainable development can be the secondary institutions of global governance.

Sustainable development is also rarely discussed as primary or secondary institutions. The World Commission of Environment and Development has defined sustainable development as "development that meets the needs of the present without compromising the ability of future generations to meet their own needs"(World Commission on Environment and Development 1987, 12). This definition has been used by all policy makers and development agencies and there is lack theoretical discussion over the meaning of sustainable development.

This research didn't bring new definition of sustainable development but argued the strategic position of sustainable development in the English School institution. There has been many research showing sustainable development as the primary institutions such as by Baker (1997)and The International Local Council for Local Environmental Initiatives (1996). International Local Council for Local Environmental Initiatives has mentioned that sustainable development consists of three secondary institutions namely economic development, community development and ecological development. The scope and the extent of the economic development, community development and ecological development enabled the sustainable development to be a primary institutions.

Instead of bringing sustainable development to be a primary institution, this article argued that sustainable development is a secondary institution of global governance. The case study of transboundary haze and forest fires is a reason for bringing sustainable development as the secondary institution of global governance.

ASEAN Way is the global governance of many problems in Southeast Asia. ASEAN Way prefers the consensual, non-legalistic and informal manner of solving disputes with the emphasis of state-centric solution(Acharya 2001). Meanwhile RSPO has adopted an inclusive and democratic decision-making by involving all related stakeholders with balanced representation in the board of committee. This a clash of global governance regarding environmental issues. The core question is on which decision-making mechanism best fitted to the contemporary environmental problems.

Global governance is about the transfer of authority from states to non-states actor. Global governance is "systems of rule at all levels of human activity - from the family to the international organization - in which the pursuit of goals through the exercise of control has transnational repercussions" (Rosenau 1995, 34). This definition didn't negate the existence of states but gives non-states actors legitimate role in the international affairs. The interaction between states and non-states actors can be a joint standard-settings, consultation forum, private self-regulation with the involvement of public actors, lobbying of state by non-state actors as shown in the figure 1. 


\section{JAPS}

Figure 2. State and Non-State Interaction in Global Governance

\begin{abstract}
Private self-regulation in the shadow of hierarchy of public actor
\end{abstract}

Public adoption of private regulation

\section{Consultation and co-}

optation of private actors

Delegation to private actors and standardsetting with participation of state

Lobbying of state by private actors

\section{Co-regulation and}

joint- decision making

Purely No State Intervention

\section{Corporation}


The secondary institution of global governance is legitimacy. The decision-making process should involve all related stakeholders. There are three components of legitimacy namely internal legitimacy, the output and throughput (Dingwerth 2007). Internal legitimacy is built based on the ability to engage with the hidden and invisible related stakeholders. Throughput legitimacy is built on the idea of equal power and access to influence the decision-making process. Output should reflect the equal and just representation of global governance.

In the case of transboundary haze and forest fires in Indonesia, RSPO and ASEAN Way is contradicting each other. ASEAN Way prefers ASEAN member states to work together under the framework of ASEAN Agreement on Transboundary Haze Pollution meanwhile RSPO has standard and criteria that prohibit the palm oil industry to use fires and illegal forest products. This is a two different kind of global governance and this research argued that pluralism also has the global governance version of transboundary haze and forest fires in Indonesia.

\section{RSPO (Rountable Sustainable Palm Oil)}

The solidarism construction was seen from the critical statement of RSPO that state was failed in preventing the deforestation and supervising the corporation behaviour. RSPO is reversing the way of governance, from top-down approach to bottom-up approach. Corporation was gathered to make their rules and this represented a change from pluralism to solidarism.

RSPO and Forest Stewardship Council (FSC) was built on the concern of the environmentalists that advised for change in customers behaviour by introducing certification and standard(Moog, Spicer and Bohm 2015). By having standard and certification, customers and corporation are indirectly protecting the forest and the environment. If there is fires in the value chain production, the corporation will not receive the certification and failed to fulfill the standard.

Losing the standard means losing business opportunities and markets. In the European market, the standard and the certification was important in marketing and product sales. The awareness of European customers in environmental issues is really high and it is reflected on the importance of the green label in their decision buying certain product and services.

Global governance has two dimensions of observable phenomenon and political program(Dingwerth and Pattberg 2006). RSPO has both of them, a concrete project of solidarism and a campaign of political norms beyond the diplomacy, great power politics, war, balance of power and international law - norms of Hedley Bull's international order. It means that we can talk about democracy and equality on RSPO. RSPO was inclusive, built from consensus from national palm oil corporation association as Malaysian Palm Oil Association, palm oil company such as Wilmar and Golden Hope as well food manufacturers and retailers(Nikoloyuk, Burns and Man 2010).Then after being inclusive, the decisionmaking process was built on the idea of equality and consensus. This is the democracy of RSPO. RSPO was giving equal representation of NGO and corporation. There is no domination either civil society or corporation.

Despite of its advantages, RSPO has its own weaknesses. As shown by Kohne (2014), small farmers have problem accessing RSPO meeting abroad. Small farmers need assistance from civil society in funding their campaign against exploitation of big companies. It is also shown that big companies have bigger resources in hiring media consultant lobbying and persuading governments and district leaders. 
In the context of forest fires and transboundary haze, many studies have evaluated the effectiveness of RSPO. In their investigative reports, Greenpeace claimed that RSPO has been failed in reducing forest fires in the RSPO members concessions area. Meanwhile, Cattau, Marlier and DeFries $(2016,4)$ claimed that "fire activity is significantly lower than on RSPO certified concessions than non-RSPO certified concessions when the likelihood of fire is low (i.e., on non-peatlands in wetter years) but not when the likelihood of fire is high". Ruysschaert and Salles (2014) even argued that there are five weaknesses of RSPO; financial compensation too small, too much room for interpretation in the guidance document, postponement of contentious issues, non-integration of RSPO within Indonesian law and lack of external control system.

\section{ASEAN Agreement on Transboundary Haze Pollution}

The pessimistic perspective toward the pluralism should be reformed. ASEAN Agreement on Transboundary Haze Pollution (AATHP) is also a form of global governance with legitimacy and sustainable development as its secondary institution. AATHP is ratified by Indonesian parliament in 2016 and AATHP has enabled Indonesia to join regional strategy in combating forest fires and haze. AATHP is not an extreme position of pluralism as advised by pluralism. ASEAN Charter has obliged all ASEAN member states to cooperate with civil society and AATHP should do the similar path.

The legitimacy criteria of AATHP is fulfilled as the states are the dominant unit of AATHP. It is important to note that states have considered environmental problems as a serious agenda and has invited and established many related stakeholders dialogue implemented by Ministry of Foreign Affairs, Ministry of Environment and Forestry or National Police. Input legitimacy and throughput legitimacy was fulfilled as there are elements of democracy especially in Indonesia and the Philippines. Meanwhile the output of AATHP has been felt as there are many suspects of forest fires and concrete handling of forest fires and transboundary haze.

This articles shows that AATHP is also a form of global governance and it is built on the foundation of pluralism. The pluralism definition of global governance would be intergovernmental and transgovernmental as shown by the AATHP. Meanwhile the solidarism definition of global government would be transnational and supranational. We can build the sustainable development with those four forms of global governance by adding the relevance of ecological development for intergovernmental, transgovernmental, supranational and transnational.

Lian and Robinson (2002)explained that AATHP is a derivative of ASEAN Way that prefers non-interference or non-intervention in other member states, consensus building and national implementation rather than using ASEAN Secretariat. They further argued that AATHP is critical in regional integration in Southeast Asia as AATHP serves as the forum for networking, institution building, data and information management, research and development and education and training.

AATHP and ASEAN Way are integral to pluralism project. Many studies have evaluated the effectiveness of AATHP and showed that AATHP were largely ineffective in combatting forest fires and haze due to the non-binding nature (Varkkey 2011, Nurhidayah, Alam and Lipman 2015, Nguitragool 2011). This article argued that AATHP has been successful in realizing the pluralism project that combining global governance, legitimacy, and sustainable development.

This article disagree with the rivalry with the solidarism and pluralism in the forms of global governance. RSPO and AATHP can work together to combat the forest fires and 
transboundary haze. Therefore solidarism and pluralism version of global governance can be boxed under the heading of global governance. It is not only the victory of solidarism but also the victory of pluralism. Then we can have an inclusive global governance by rejecting the rivalry of solidarism and pluralism.

\section{International Pressures vs Indonesia}

ASEAN Agreement on Transboundary Haze Pollution is considered ineffective for European government. The recurrence of forest fires and transboundary haze marked big question for the implementation of AATHP. European government proposed a more strict policies toward Indonesian government. We see another pluralism-solidarism debate and the solidarism seems winning the battle. The buyer of Indonesian palm oil and pulp products is the European and the imposition of green label by RSPO and FSC gives additional burden to the corporation. Forest fires and transboundary haze was considered as global issue due to the increasing campaign of deforestation and climate change. The state-centric framework of environmental governance was obsolete as there are less tangible evidences of effectiveness and support from European government.

The European Union is a solidarist. They are able to transform the fuel industries to renewable energy and encourage the involvement of civil society in the decision-making process. However, the European are not satisfied with its regional policies and attempted to bring their normative agenda to the global level.

French government proposed amendment of Biological diversity law to impose tax 300 Euro per ton of crude palm oil (CPO). The rational of CPO tax is the failure of governments and corporation combatting deforestation, forest fires and transboundary haze (Alfani 2017). By imposing tax, there will be less incentive for customers using Indonesian palm oil. Indonesian palm oil will be more expensive. This plan is canceled but the environmental activists are keep pushing for tighter regulation for corporation in the environmental sector.

Not only the French, Singapore government also introduced Transboundary Haze bill that able to impose punishment for Indonesian companies that was responsible for forest fires and transboundary haze. Singaporean were so disappointed with the responses from Indonesian government and urged concrete responses to combat the forest fires and transboundary haze. Singapore introduced Transboundary Haze Pollution act that has extraterritorial reach that enable the Singaporean police to arrest individuals and corporations that are responsible to forest fires and transboundary haze. This bill has provoked massive protests from Indonesian government as it is considered as direct intervention of Indonesian sovereignty.

Indonesia was unable to arrest the responsible corporation on land fires and deforestation and it is even further that government has allowed the conversion of forest into plantation and wood industry. There is a term of haze of democracy(Berenschot 2015). It is alleged that provincial and district leader are bribed in order to get business permit in palm oil and wood sector. The bribery are used to fund the election campaign and approval from political parties. The democracy is not campaigning for environmental values and norm and instead encouraging more deforestation and agriculture expansion. Again, we see the victory of solidarism.

However, Indonesia government swiftly addressed the concern of European countries. Indonesian government established Indonesian Sustainable Palm Oil (ISPO). ISPO is a part of Indonesian government to socialize the environmental issues to palm oil industry. ISPO has many similarities with RSPO but it is mandatory to all palm oil companies in Indonesia. 
The presence of ISPO has provoked protests and critics from environmental critics due to its state-centric mechanism. However, the presence of ISPO symbolized the relevancy of pluralism in global governance. ISPO is a part of pluralism in implementing and maintaining the idea of global governance with its secondary institution of sustainable development and legitimacy.

Again the conflict of pluralism and solidarism as suggested by English School theory can be reformed. The presence of French CPO tax and Singaporean Transboundary Haze Pollution Act didn't mean to sharpen the debate between solidarism and pluralism. The presence of ASEAN Transboundary Haze Pollution Agreement and ISPO symbolized the similarities between pluralism with solidarism. This research argued that solidarism and pluralism can be neatly put under a single primary institution of global governance by using the case study of forest fires and transboundary haze in Indonesia.

\section{Conclusion and Recommendation}

This article would like to critically highlight the domination of solidarism in global governance. The increasing power of civil society and corporation has undermined the role of states including in environmental issues. Solidarism proposed for more intervention from non-state actors toward status quo due to the failure of government in effectively addressing the environmental problems. In other words, pluralism is claimed as obsolete.

The domination of solidarism in global governance is tested in the case study of forest fires and transboundary haze in Indonesia. Forest fires and transboundary haze has been perpetual disaster. Thousands of peoples in Indonesia, Malaysia and Singapore has been the victim of this disaster. It has killed hundreds of lives and stopped many activities in public and private places. Greenpeace and many environmental activists has accused government in neglecting the disaster and ineffective in enforcing the law. Roundtable Sustainable Palm Oil (RSPO) has been established in order to bring effective alternative in combatting the fires and the haze. The alliance of civil society and corporations is powerful in influencing customers and palm oil corporation.

This articles has two findings. Firstly, RSPO as solidarism projects has its advantages and weaknesses that need for reform and revision. Many research have evaluated the effectiveness of RSPO and showed of its shortcomings. Secondly, pluralism is not neglecting the global governance as there is ASEAN Agreement on Transboundary Haze Pollution that combined global governance with sustainable development and legitimacy.

The rivalry mode of interaction of solidarism and pluralism is not useful in explaining the dynamics of forest fires and transboundary haze in Indonesia. To be able to be a grand theory, English School should adopt an inclusive approach by reforming the incommensurability of pluralism and solidarism. By taking global governance as primary institution, this research argued that pluralism and solidarism has many similarities and can be boxed under the heading of global governance. 


\section{REFERENCES}

\section{Books}

Acharya, Amitav. 2001. Constructing a Security Community in Southeast Asia: the Problem of Regional Order. London: Routledge.

Alfani, Abdul Hamid. 2017. Indonesia on Palm Diplomacy in Europe: Approaches towards Boycotts (2006 - 2016). Cikarang: President University.

Beitz, Charles. 1979. Political Theory and International Relations. Princeton, New Jersey: Princeton University Press.

Bull, Hedley. 1977. The Anarchical Society: A Study of Order in World Politics. Basingstoke: Palgrave.

Buzan, Barry. 2004. From International to World Society: English School Theory and the Social Structure of Globalisation. Cambridge: Cambridge University Press.

Cohn, Theodore. 2012. Global Political Economy. 6th. Boston: Pearson.

Dingwerth, Klaus. 2007. The New Transnationalism: Transnational Governance and Democratic Legitimacy. Basingstoke: Palgrave MacMillan.

Greenpeace. 2007. Cooking the Climate. Amsterdam: Greenpeace International.

Humphreys, David. 2006. Logjam: Deforestation and the Crisis of Global Governance. London: EarthScan.

Kopra, Sanna. 2016. With Great Power Comes Great Responsibility? China and the International Practice of Climate Responsibility. Tampere: Tampere University Press.

The International Council for Local Environmental Initiatives. 1996. The Local Agenda 21: An Introduction to Sustainable Development Planning. Ottawa: The International Council for Local Environmental Initiatives.

Wight, Martin. 1992. International Theory: The Three Tradition . New York: Holmes \& Meier.

World Commission on Environment and Development. 1987. Our Common Future. Oxford: Oxford University Press.

\section{Article in Books}

Baker, Susan, Maria Kousis, Dick Richardson, and Stephen Young. 1997. "Introduction: The theory and practice of sustainable development in EU perspective." In The Politics of Sustainable Development: Theory, Policy and Practice within the European Union, by Susan Baker, Maria Kousis, Dick Richardson and Stephen Young, 1-41. London: Routledge.

Börzel, Tanja A., and Thomas Risse. 2005. "Public-Private Partnerships: Effective and Legitimate Tools of International Governance?" In Complex Sovereignty: On the Reconstitution of Political Authority in the 21st Century, by Edgar Grande and Louis W. Pauly, 195-216. Toronto: University of Toronto Press.

Bull, Hedley. 1966. "Grotian Conception on International Society." In Diplomatic Investigation: Essays in the Theory of International Politics, by Herbert Butterfield and Martin Wight, 51-73. Michigan: Allen \& Unwin.

Lian, Koh Kheng, and Nicholas A. Robinson. 2002. "Regional Environmental Governance: Examining the Association of Southeast Asian Nations (ASEAN) Model." In Global Environmental Governance: Options and Opportunities, by Daniel C. Esty and Maria H. Ivanova, 101-121. Connecticut: Yale School of Forestry \& Environmental Studies. 
Paterson, Mathew. 2005. "Global Environmental Governance." In International Society and Its Critics, 163-178. Oxford: Oxford University Press.

\section{Journal}

Bram, Deni. 2012. "Kejahatan Korporasi dalam Pencemaran Lintas Batas Negara: Studi Pencemaran Kabut Asap Kebakaran Hutan di Indonesia." Law Review 11 (3): 377393.

Cattau, Megan E, Miriam E Marlier, and Ruth DeFries. 2016. "Effectiveness of Roundtable on Sustainable Palm Oil (RSPO) for reducing fires on oil palm concessions in Indonesia from 2012 to 2015." Environmental Research Letters 1-11.

Dauvergne, Peter. 1998. "The Political Economy of Indonesia's 1997 Forest Fires." Australian Journal of International Affairs 52 (1): 13-17.

Dauvergne, Peter. 1994. "The Politics of Deforestation in Indonesia." Pacific Affairs 66 (4): 497-518.

Dingwerth, Klaus, and Philipp Pattberg. 2006. "Global Governance as a Perspective on World Politics ." Global Governance 185-203.

Falkner, Richard. 2012. "Global environmentalism and the greening of international society." International Affairs 503-522.

Gregory, Sam. 2012. "Kony 2012 Through A Prism of Video Advocacy Practices and Trends." Journal of Human Rights Practices 463-468.

Kohne, Michiel. 2014. "Multi-stakeholder Initiative governance as assemblage: Rountable Sustainable Palm Oil as a Political Resource in Land Conflicts related to Oil Palm Plantation." Agriculture Humanity 469-480.

Moog, Sandra, Andre Spicer, and Steffen Bohm. 2015. "The Politics of Multi-Stakeholder Initiatives: The Crisis of the Forest Stewardship Council." Journal of Business Ethics 469-493.

Nguitragool, Paruedee. 2011. "Negotiating the Haze Treaty Rationality and Institutions in the Negotiations for the ASEAN Agreement on Transboundary Haze Pollution (2002)." Asian Survey 51 (2): 356-378.

Nikoloyuk, Jordan, Tom Burns, and Reinier de Man. 2010. "The promise and limitations of partnered governance: the case of sustainable palm oi." Corporate Governance 59-72.

Nurhidayah, Laely, Shawkat Alam, and Zada Lipman. 2015. "The Influence of International Law upon ASEAN Approaches in Addressing Transboundary Pollution in Southeast Asia." Contemporary Southeast Asia 37 (2): 183-210.

Rosenau, James. 1995. "Governance in the Twenty-First Century." Global Governance 1343.

Ruysschaert, Denis, and Denis Salles. 2014. "Towards global voluntary standards: Questioning the effectiveness in attaining conservation goals The Case of the Roundtable on Sustainable Palm Oil." Ecological Economics 438-446.

Varkkey, Helena Muhammad. 2011. "Addressing Transboundary Haze Through Asean: Singapore's Normative Constraints." Journal of International Studies 83-101.

Varkkey, Helena Muhammad. 2011. "ASEAN as a thin community: the case against adopting the EU Acid Rain Framework for transboundary haze management in Southeast Asia." Malaysian Journal of History, Politics \& Strategic Studies 38 (2): 1-26.

Varkkey, Helena Muhammad. 2009. "Indonesia Perspectives on Managing the ASEAN Haze." Jurnal Sarjana 24 (1): 83-101.

Varkkey, Helena Muhammad. 2012. "The ASEAN Way and Haze Mitigation Efforts." Journal of International Studies 8: 77-97. 


\section{Websites}

Berenschot, Ward. 2015. "Haze of Democracy." October-December. Accessed February 14, 2016. http://www.insideindonesia.org/haze-of-democracy.

Tan, Eugene. 2015. Going beyond the law to fight transboundary haze. September 22. Accessed July 10, 2017. http://www.todayonline.com/commentary/going-beyondlaw-fight-transboundary-haze?singlepage=true. 